\title{
MDA and GSH-Px activity \\ in transition dairy cows under seasonal variations and their relationship with reproductive performance
}

\author{
Hatice Esra Colakoglu ${ }^{1}$, Murat Onur Yazlik ${ }^{1}$, Ufuk Kaya ${ }^{2}$, \\ Ekrem Cagatay Colakoglu ${ }^{3}$, Serdal Kurt ${ }^{1}$, Burcu Oz ${ }^{1}$, \\ Rustem Bayramoglu ${ }^{4}$, Mehmet Rifat Vural ${ }^{1}$, Sukru Kuplulu ${ }^{1}$ \\ ${ }^{1}$ Department of Obstetrics and Gynecology, ${ }^{2}$ Department of Biostatistics, ${ }^{3}$ Department of Internal Medicine, \\ Faculty of Veterinary Medicine, University of Ankara, 06110, Ankara, Turkey \\ ${ }^{4}$ Veterinary Medicine, Farm Animal Management Practitioner, Western Thrace, Greece
}

Received: July 9, 2017 Accepted: December 5, 2017

\begin{abstract}
Introduction: The purpose of the current study was to evaluate the blood glutathione peroxidase (GSH-Px) and malondialdehyde (MDA) levels under seasonal variations in dairy cows during transition period, and to assess the relationship between chosen reproductive parameters, GSH-Px, and MDA. Material and Methods: Holstein cows calving in January were assigned into winter group $(\mathrm{n}=42)$, while cows calving in August were assigned into summer group $(\mathrm{n}=42)$. Blood samples were collected from the jugular vein 21, 14, and 7 days before calving, at calving (0 day), and 7, 14, and 21 days after calving. Reproductive parameters obtained from farm records were evaluated. Results: In both groups of cows, GSH-Px activity decreased from 21 days before calving to day 0 , and it gradually continued to increase until 21 days after calving. GSH-Px activity was higher in winter group compared to summer group during the transition period $(\mathrm{P}<0.05)$. MDA levels in both groups increased over time starting from 21 days before calving to 0 day, but it gradually decreased thereafter. MDA levels were higher in summer group compared to winter group during the transition periods $(\mathrm{P}<0.05)$. Summer group of cows showed higher intervals of calving-to-oestrus, calving-to-conception, and higher insemination index $(\mathrm{P}<0.01)$. Negative correlation was recorded between GSH-Px and MDA during all examination days $(\mathrm{P}<0.01)$. MDA levels correlated with calving to conception interval on day 21 before calving and day $0(\mathrm{P}<0.01)$ and insemination index on day 0 and 21 days after calving $(\mathrm{P}<0.01)$. GSH-Px activity was negatively correlated with calving to conception interval on day 21 before calving, day 0 , and 21 days $(\mathrm{P}<0.01)$ after calving. Negative correlation on day 21 before calving and day 0 was also determined between GSH-Px and insemination index $(\mathrm{P}<0.01)$. Conclusion: This study showed that blood oxidant and antioxidant levels have affected the fertility parameters in cows under seasonal variations.
\end{abstract}

Keywords: cow, glutathione peroxidase, malondialdehyde, reproductive performance, season.

\section{Introduction}

Transition period has been defined as the most critical period in relation to health status of dairy cows during the lactation cycle. Transition dairy cows show dramatic changes in energy balance, alteration of the immune system, and oxidant/antioxidant balance (25, 40). These alterations can affect the health and fertility of dairy cows (26). In this period, the metabolic and oxygen requirements of dairy cows increase with foetal development and lactation (18, 39). Increased requirements can result in increased production of reactive oxygen species (ROS) negatively affecting the oxidative balance during transition period $(1,39)$. ROS lead to damage of biological macromolecules of cells and disruption of metabolism and physiology. These alterations in cells also lead to metabolic disorders and development of diseases in dairy cows $(24,33)$. Antioxidants can be defined as substances that delay, prevent, or remove the oxidative damage to target molecules (20).

Under physiological conditions, ROS are neutralised by the antioxidant system (30). Imbalance between increased ROS production and reduced capacity of antioxidant system induces oxidative stress (5, 8 18). Oxidative stress and antioxidant status 
depend on the stage of lactation (33), nutrition (17), disease (30), and seasonal variations (27). It has also been reported that heat stress, depending on the climatic changes, induces the free radicals production and reduction in plasma antioxidant activity $(19,28)$.

Some studies considering the effect of heat stress on reproductive performance and health status of cows are available $(13,14)$. Heat stress reduces the duration and intensity of oestrus, decreases the conception rates, and increases the number of inseminations $(14,42)$. During warm season, there is an increase in the frequency of ovarian cysts and pregnancy losses (12, 14). The effect of heat stress on the fertility of dairy cows is associated with several mechanisms including feed intake, rumen physiology, acid-base balance, and imbalance of oxidant/antioxidant activity and hypothalamo-hypophyseal-ovarian axis $(12,14)$.

The purpose of the study was to evaluate the blood glutathione peroxidase (GSH-Px) and malondialdehyde (MDA) levels in transition dairy cows under seasonal variations. Possible relations of these oxidantantioxidant parameters with fertility were also investigated.

\section{Material and Methods}

Study design and animals. The present study was conducted at a commercial dairy farm in Western Thrace ( $\left.41^{\circ} 8^{\prime} 11^{\prime \prime} \mathrm{N}, 24^{\circ} 52^{\prime} 57^{\prime \prime} \mathrm{E}\right)$ with Holstein cows housed in free stall resting barns. All animals were fed a mixed ad libitum ration containing grass, corn silage, and commercial concentrate twice a day. Cows were milked with automatic milking system, twice daily. The age of the cows $(n=84)$ ranged from 3 to 6 years. All cows were pregnant and clinically healthy. Average ambient temperature and relative humidity during the study are shown in Table 1.

Table 1. Annual climatological data during study (mean \pm SD)

\begin{tabular}{llll}
\hline \multirow{2}{*}{ Months } & \multicolumn{2}{c}{ Air temperature $\left({ }^{\circ} \mathrm{C}\right)$} & $\begin{array}{l}\text { Precipitation } \\
(\mathrm{mm})\end{array}$ \\
\cline { 2 - 4 } & Max. & Min. & $69.6 \pm 0.75$ \\
\hline January & $10.3 \pm 0.17$ & $6.1 \pm 0.87$ & $27.0 \pm 1.21$ \\
\hline February & $13.3 \pm 0.86$ & $5.7 \pm 1.51$ & $134.0 \pm 1.51$ \\
\hline March & $16.1 \pm 0.47$ & $6.4 \pm 1.04$ & $181.6 \pm 0.88$ \\
\hline April & $18.2 \pm 0.21$ & $9.8 \pm 1.28$ & $46.0 \pm 1.08$ \\
\hline May & $23.8 \pm 1.21$ & $12.6 \pm 1.74$ & $85.4 \pm 1.17$ \\
\hline June & $29.8 \pm 1.31$ & $17.4 \pm 1.07$ & $18.6 \pm 1.62$ \\
\hline July & $33.6 \pm 0.28$ & $19.6 \pm 1.17$ & $32.0 \pm 1.04$ \\
\hline August & $34.3 \pm 0.89$ & $20.4 \pm 1.08$ & $83.6 \pm 1.19$ \\
\hline September & $26.2 \pm 0.54$ & $16.5 \pm 1.24$ & $42.6 \pm 1.36$ \\
\hline October & $20.7 \pm 1.2$ & $11.7 \pm 1.54$ & $32.8 \pm 1.27$ \\
\hline November & $15.2 \pm 0.15$ & $7.9 \pm 1.47$ & $127.5 \pm 1.42$ \\
\hline December & $12.2 \pm 1.23$ & $5.4 \pm 1.15$ & \\
\hline
\end{tabular}

The animals were divided into two equal groups according to calving season. The cows calving in January were assigned into winter group, while cows calving in August were assigned into summer group.

Collection of blood samples and biochemical analysis. A total of $9 \mathrm{ml}$ of blood were collected from the jugular vein into tubes with $\mathrm{K}_{2} \mathrm{EDTA}$ (for MDA analysis) and into tubes with heparin (for GSH-Px analysis) at 21,14 , and 7 days before calving $(-21,-14$, -7 ), at calving (0), and 7, 14, and 21 days after calving $(7,14,21)$. Blood samples were collected early in the morning, always at the same time, with the same environmental conditions. MDA levels were analysed with the method described by Uchiyama and Mihara (43). GSH-Px activity was also determined by the method of Hefamen et al. (19). The results of MDA and GSH-Px were expressed as $\mu \mathrm{mol} / \mathrm{L}$ and units $/ \mathrm{mg} \mathrm{Hb}$, respectively.

Evaluation of reproductive performance. Reproductive performance was assessed based on the calving-to-oestrus interval, calving-to-conception interval, and insemination index (service/conception).

Statistical analysis. Before performing the statistical analysis, data were examined for normality as parametric test assumptions. Descriptive statistics for each variable were calculated and presented as mean standard deviation ( \pm SD). Pearson's correlation coefficient was used to determine the correlation between MDA, GSH-Px, and fertility parameters except insemination index. Spearman correlation coefficient was used to determine the correlation between MDA, GSH-Px, and insemination index since insemination index was not normally distributed. To test the differences in each parameter between time sampling in winter and summer group, two-way ANOVA with repeated measures design with group (winter, summer) as between-subject factor, and days from calving as within-subject factor were used after performing Mauchly's sphericity test to check the sphericity assumption. When a significant difference was revealed, any significant terms were compared by simple effect analysis with Bonferroni adjustment. The calving-to-oestrus interval and calving-to-conception interval were evaluated with a $t$-test. Insemination index was also analysed by the Mann-Whitney $U$ test. $\mathrm{P}$ value of $<0.05$ was considered to indicate statistical significance. SPSS for Windows 14.1 (Licence No. 9869264) was used for analyses of the data.

\section{Results}

MDA levels in both groups of cows increased over time starting from day -21 to day 0 but it gradually decreased thereafter (Table 2). MDA levels of winter group ranged from $3.21 \pm 0.29$ to $3.3 \pm 0.17 \mu \mathrm{mol} / \mathrm{L}$ while that of summer group ranged from $3.59 \pm 0.17$ to $3.4 \pm 0.05 \mu \mathrm{mol} / \mathrm{L}$. MDA level was also higher in 
summer group compared to winter group during the transition period $(\mathrm{P}<0.05)$.

Table 2. The values of MDA $(\mu \mathrm{mol} / \mathrm{L})$ in summer and winter groups $($ mean $\pm \mathrm{SD})$

\begin{tabular}{cll}
\hline \multirow{2}{*}{$\begin{array}{c}\text { Days before and } \\
\text { after calving }\end{array}$} & \multicolumn{2}{c}{ Group } \\
\cline { 2 - 3 } & $\begin{array}{l}\text { Winter }(\mathrm{n}=42) \\
\mathrm{X} \pm \mathrm{SD}\end{array}$ & $\begin{array}{l}\text { Summer }(\mathrm{n}=42) \\
\mathrm{X} \pm \mathrm{SD}\end{array}$ \\
\hline-21 & $3.21 \pm 0.29^{\mathrm{e}, \mathrm{B}}$ & $3.59 \pm 0.17^{\mathrm{c}, \mathrm{A}}$ \\
\hline-14 & $3.19 \pm 0.12^{\mathrm{e}, \mathrm{B}}$ & $3.51 \pm 0.05^{\mathrm{d}, \mathrm{A}}$ \\
\hline-7 & $3.31 \pm 0.09^{\mathrm{d}, \mathrm{B}}$ & $3.62 \pm 0.1^{\mathrm{c}, \mathrm{A}}$ \\
\hline 0 & $3.69 \pm 0.28^{\mathrm{a}, \mathrm{B}}$ & $4.1 \pm 0.21^{\mathrm{a}, \mathrm{A}}$ \\
\hline 7 & $3.54 \pm 0.21^{\mathrm{b}, \mathrm{B}}$ & $3.87 \pm 0.18^{\mathrm{b}, \mathrm{A}}$ \\
\hline 14 & $3.4 \pm 0.13^{\mathrm{c}, \mathrm{B}}$ & $3.6 \pm 0.03^{\mathrm{c}, \mathrm{A}}$ \\
\hline 21 & $3.3 \pm 0.17^{\mathrm{d}, \mathrm{B}}$ & $3.4 \pm 0.05^{\mathrm{e}, \mathrm{A}}$ \\
\hline
\end{tabular}

a-e means with different small letters in the same column are significantly different $(\mathrm{P}<0.05)$

${ }^{A-B}$ means with different capital case letters in the same row are significantly different $(\mathrm{P}<0.05)$

In both groups of cows, GSH-Px activity decreased from day -21 to day 0 , and it gradually continued to increase until 21 days after calving (Table 3). The GSH-Px activity in winter group ranged from $3.16 \pm 0.03$ to $2.1 \pm 0.021 \mathrm{U} / \mathrm{g} \mathrm{Hb}$, while that in summer group ranged from $2.97 \pm 0.16$ to $1.8 \pm 0.08 \mathrm{U} / \mathrm{g} \mathrm{Hb}$.
GSH-Px activity was also higher in winter group compared to summer group during the transition period $(\mathrm{P}<0.05)$.

Table 3. The values of GSH-Px activity (units/mg $\mathrm{Hb}$ ) in summer and winter groups (mean $\pm \mathrm{SD})$

\begin{tabular}{cll}
\hline \multirow{2}{*}{$\begin{array}{c}\text { Days before and } \\
\text { after calving }\end{array}$} & $\begin{array}{l}\text { Group } \\
\text { Winter }(\mathrm{n}=42)\end{array}$ & $\begin{array}{l}\text { Summer }(\mathrm{n}=42) \\
\mathrm{X} \pm \mathrm{SD}\end{array}$ \\
\hline-21 & $3.16 \pm 0.03^{\mathrm{a}, \mathrm{A}}$ & $2.97 \pm 0.16^{\mathrm{a}, \mathrm{B}}$ \\
\hline-14 & $3.19 \pm 0.08^{\mathrm{a}, \mathrm{A}}$ & $2.78 \pm 0.11^{\mathrm{b}, \mathrm{B}}$ \\
\hline-7 & $2.7 \pm 0.11^{\mathrm{b}, \mathrm{A}}$ & $2.0 \pm 0.21^{\mathrm{c}, \mathrm{B}}$ \\
\hline 0 & $1.7 \pm 0.12^{\mathrm{f}, \mathrm{A}}$ & $1.52 \pm 0.08^{\mathrm{f}, \mathrm{B}}$ \\
\hline 7 & $1.85 \pm 0.04^{\mathrm{e}, \mathrm{A}}$ & $1.63 \pm 0.12^{\mathrm{e}, \mathrm{B}}$ \\
\hline 14 & $1.98 \pm 0.16^{\mathrm{d}, \mathrm{A}}$ & $1.69 \pm 0.29^{\mathrm{e}, \mathrm{B}}$ \\
\hline 21 & $2.1 \pm 0.021^{\mathrm{c}, \mathrm{A}}$ & $1.8 \pm .08^{\mathrm{d}, \mathrm{B}}$ \\
\hline
\end{tabular}

a-f means with different small letters in the same column are significantly different $(\mathrm{P}<0.05)$

${ }^{\mathrm{A}-\mathrm{B}}$ means with different capital case letters in the same row are significantly different $(\mathrm{P}<0.05)$

Compared to winter group, summer group had a longer calving to the first oestrus interval, a longer calving to conception interval, and a higher insemination index (P $<0.01$ for all) (Table 4). Correlations between the parameters in summer and winter groups are shown in Table 5.

Table 4. Fertility parameters of summer and winter cows (mean \pm SD)

\begin{tabular}{lll}
\hline \multirow{2}{*}{ Fertility parameters } & \multicolumn{2}{c}{ Group } \\
\cline { 2 - 3 } & $\begin{array}{l}\text { Winter }(\mathrm{n}=42) \\
\mathrm{X} \pm \mathrm{SD}\end{array}$ & $\begin{array}{l}\text { Summer }(\mathrm{n}=42) \\
\mathrm{X} \pm \mathrm{SD}\end{array}$ \\
\hline Calving to oestrus interval & $34.73 \pm 8.35^{\mathrm{B}}$ & $46.40 \pm 6.88^{\mathrm{A}}$ \\
\hline Calving to conception interval & $99.6 \pm 29.12^{\mathrm{B}}$ & $145.83 \pm 47.8^{\mathrm{A}}$ \\
\hline Insemination index & $1.73 \pm 0.91^{\mathrm{B}}$ & $2.93 \pm 0.91^{\mathrm{A}}$ \\
\hline
\end{tabular}

${ }^{A-B}$ means with different small letters in the same row are significantly different $(\mathrm{P}<0.01)$

Table 5. The correlation coefficients between MDA, GSH-Px, and fertility parameters in winter and summer groups

\begin{tabular}{|c|c|c|c|c|c|c|c|}
\hline \multirow[b]{2}{*}{$\begin{array}{l}\text { Days before } \\
\text { and after } \\
\text { calving }\end{array}$} & \multirow[b]{2}{*}{$\begin{array}{l}\text { MDA } \\
\text { and } \\
\text { GSH-Px }\end{array}$} & \multicolumn{3}{|c|}{ MDA } & \multicolumn{3}{|c|}{ GSH-Px } \\
\hline & & $\begin{array}{l}\text { Calving to first } \\
\text { oestrus interval }\end{array}$ & $\begin{array}{l}\text { Calving to } \\
\text { conception } \\
\text { interval }\end{array}$ & Insem. index & $\begin{array}{l}\text { Calving to first } \\
\text { oestrus interval }\end{array}$ & $\begin{array}{l}\text { Calving to } \\
\text { conception interval }\end{array}$ & $\begin{array}{l}\text { Insem. } \\
\text { index }\end{array}$ \\
\hline-21 & $0.66 * *$ & $\mathrm{~ns}$ & $0.44 * *$ & ns & ns & $0.504 * *$ & $0.53 * *$ \\
\hline-14 & $0.591 * *$ & $\mathrm{~ns}$ & $\mathrm{~ns}$ & ns & ns & ns & ns \\
\hline-7 & $0.542 * *$ & $\mathrm{~ns}$ & $\mathrm{~ns}$ & $\mathrm{~ns}$ & $\mathrm{~ns}$ & ns & $\mathrm{ns}$ \\
\hline 0 & $0.682 * *$ & $\mathrm{~ns}$ & $0.366^{* *}$ & $0.353 * *$ & ns & $0.37 * *$ & $0.469 * *$ \\
\hline 7 & $0.608 * *$ & $\mathrm{~ns}$ & $\mathrm{~ns}$ & $\mathrm{~ns}$ & ns & ns & $\mathrm{ns}$ \\
\hline 14 & $0.433 * *$ & $\mathrm{~ns}$ & $\mathrm{~ns}$ & $\mathrm{~ns}$ & $\mathrm{~ns}$ & ns & $\mathrm{ns}$ \\
\hline 21 & $0.51 * *$ & ns & ns & $0.282 * *$ & ns & $0.34 * *$ & ns \\
\hline
\end{tabular}

$* \mathrm{P}<0.05, * * \mathrm{P}<0.01 ; \mathrm{ns}-$ not significant, $\mathrm{n}=84)$ 


\section{Discussion}

The results obtained in the present study showed that both groups of cows showed higher oxidative stress and lower antioxidant activity until calving compared to cows in postpartum period. In addition, summer group of cows had higher oxidative stress and lower antioxidant activity during transition period. It has been demonstrated that heat stress negatively affects the oxidative balance of cows during the transition period. While blood antioxidant activity showed negative correlation, oxidant activity had positive correlation with fertility parameters.

MDA is the last product of lipid peroxidation and therefore changes of MDA concentrations can be used as a biomarker of oxidative stress (8). In findings of the present study, MDA levels gradually increased in both groups from -21 to calving days. Thereafter, it continuously decreased after calving in both groups. Although MDA levels gradually decreased after calving, blood MDA levels were still quite higher compared to levels before calving. The results contained by research groups regarding MDA levels in prepartum and lactation period are inconsistent. While some authors reported no significant changes in plasma MDA levels during periparturient period $(9,34)$, others described increased MDA levels around calving $(5,6)$. Sharma et al. (37) noted that plasma MDA level was significantly higher in early lactating cows as compared to advanced pregnant cows. Konvicna et al. (22) reported that the highest serum levels of MDA were found in the first week after parturition compared to antepartum and postpartum times. In addition, some authors have also defined a similar transient increase in MDA levels in dairy cows in the same period after calving $(29,36)$. Observations of the current study are consistent with previous reports, and data obtained from the study may show that calving and lactation affects the blood MDA levels as a cause of oxidative stress. In prepartum period, metabolic requirements of cows increase for foetal development and colostrogenesis. This demand also requires energy and oxygen, which can result in increased ROS production. With the onset of lactation, energy, and oxygen requirements reach much higher levels than prepartum. Higher MDA levels are also available in the postpartum period.

GSH-Px and SOD enzymes are the major antioxidant defence components in protecting the cells against increased $\operatorname{ROS}(1,22)$. Data regarding the relationship between GSH-Px activity and lactation stage have been obtained in previous studies $(5,8,22$, 33). However, previous results are controversial. In the present study, GSH-Px activity gradually decreased in both groups from -21 to calving days. Although GSHPx activity gradually increased after calving, blood levels of GSH-Px activity were significantly lower after calving compared to those before calving. Some authors noted that antioxidant capacity in the peripartum period of cows is insufficient to neutralise the increase in $\operatorname{ROS}(5,8)$. Konvicna et al. (22) observed that the mean GSH-Px activity of cows in the first week after calving was lower compared to the cows between six and nine weeks after calving. Aitken et al. (2) described that GSH-Px activity has increased during early lactation. Pilarczyk et al. (33) reported that the highest serum activity of GSH-Px was found during the first two months of lactation and the lowest activity was in dry cows. Cigliano et al. (10) also reported that GSH-Px activity was lower in early lactation than in mid-late lactating cows. Festila et al. (16) described that the mean blood GSH-Px activity in dairy cows was higher in advanced gestation compared to the lactation, and after calving GSH-Px activity has started to increase again. However, these different values of GSH-Px activity were not statistically significant. Similar to the findings of Festila et al. (16), Sharma et al. (37) did not observe any significant differences in blood GSH-Px activity between advanced pregnant and early lactating cows. The current study showed that GSH-Px activity had variations during transition period similar to reports by Konvicna et al. (22), Aitken et al. (2), Pilarczyk et al. (33), and Cigliano et al. (10). The highest GSH-Px activity was found before calving and gradually increased following the calving. It is possible to explain the changes in GSH-Px activity as increasing oxidative stress during the calving period and gradually decreasing oxidative stress during the early lactation period.

Exposure to heat stress during the hottest season causes the oxidant/antioxidant imbalance $(23,28)$. Heat stress also causes a reduction in plasma antioxidant activity increasing the production of free radicals and decreasing endogenous synthesis of antioxidants (23, 24). Measuring the antioxidant and oxidant activities is very important to evaluate the effect of summer high ambient temperature (35). Stress causes an increase in the glucocorticoid levels. It is also associated with decrease in functions of the immune system cells (41). High levels of glucocorticoids have decreased blood glutathione and erythrocyte superoxide dismutase activity in rats $(7,31)$, goats (3), and cows (28). Some authors pointed out the increased oxidant and decreased antioxidant activity during the summer months $(6,23$, 28). Heat stressed cows had lower total antioxidants after calving during summer than those calving in winter (42). A decrease in blood GSH-Px activity has also been observed in high ambient temperature during summer $(6,35)$. Similar to GSH-Px, blood MDA levels are affected by heat stress during the hottest season. In the study presented here, we investigated blood GSH-Px and MDA levels in cows with different calving seasons. Compared to winter and summer seasons, blood GSH-Px activity was significantly higher in winter group than that in summer group during the transition period. Cows calving in summer had a higher blood MDA levels than those calving in winter. This finding is consistent with previous reports $(6,28,35)$. 
In contrast, some authors have found that cows have higher blood oxidant levels and lower antioxidant activity during winter compared to summer period (38). The same authors also explained that maintenance of cows on pasture field in summer period has increased antioxidant activity. However, heat stress during the summer period significantly affects bovine physiology causing a decrease in feed intake and increasing body temperature. This can result in increased energy demand and lipolyses of body reserves, which leads to elevated free radicals production and reduced antioxidant activity $(8,23)$. The data obtained in the current study indicated that blood GSH-Px activity and MDA levels in cows would be influenced by seasonal variations (temperature and humidity) during the transition period and the summer group had more oxidative stress compared to cows in winter.

Because of the stimulating effect of heat stress on the activity of the hypothalamic-pituitary-adrenal axis, marked increase in serum cortisol levels was reported in cows $(21,28)$. However, increased levels of glucocorticoids block the follicular development and ovulation (11). Some studies showed that heat stress reduced the duration and intensity of oestrus, reduced the conception rates, and increased the number of inseminations $(15,42)$. Wolfenson et al. (44) also indicated that oestradiol production by granulosa cells is lower during summer season as a result of impaired dominant follicle development, which leads to an impaired corpus luteum formation with a low progesterone production. Moreover, heat stress leads to increased free radical production and decreased antioxidant activity (28). The elevation of free radicals has affected strongly all body systems including reproductive performance of males and females (28). Higher oxidant levels in serum and follicular fluid was associated with infertility in women (32). In addition, it has been reported that oxidative stress is negatively correlated with ovarian oestradiol-17 $\beta$ concentrations $(4,26)$ and this situation may result in ovarian disfunction. In the present study the calving-to-oestrus interval, the calving-to-conception interval, and the insemination index (rate) were higher in cows calving in summer with high levels of MDA and low GSH-Px activity. It was found that cows calving in winter had better reproductive performance than those calving in summer. Additionally, at different times of the transition period in both groups, significantly positive correlations between fertility parameters and MDA levels were observed, while negative correlations were found between fertility parameters and GSH-Px activity. It is possible to say that higher oxidant level and lower antioxidant activity cause poor reproductive performance. Blood MDA and GSH-Px activity at calving time also seem to affect the fertility parameters in both groups as well. Similar to our results, Turk et al. (42) reported that cows in summer group had higher number of services per conception and longer calving-to-conception interval than winter cows. These authors also found a negative correlation between antioxidant activity and calving-to-conception interval, similarly to our results. Findings obtained in the current study may suggest that blood oxidant and antioxidant levels can affect fertility parameters. Fertility parameters of summer cows are more affected by the heat stress and oxidant-antioxidant imbalance during the transition period.

In conclusion, compared to postpartum period, both groups of cows had oxidative stress until calving. However, summer group of cows had higher oxidative stress and lower antioxidant activity during transition period. Reproductive performance is associated with GSH-Px activity and MDA levels. We suggest that GSH-Px and MDA would be useful in evaluation of the fertility of dairy cows.

Conflict of Interests Statement: The authors declare that they there is no conflict of interests regarding the publication of this article.

Financial Disclosure Statement: This study was funded by the authors of manuscript.

\section{Animal Rights Statement: None required.}

This study was presented at the $18^{\text {th }}$ International Congress on Animal Reproduction in Tours, France, 2016 (MDA and GSH-Px activity in transition dairy cows under seasonal variations and their relationship with reproductive performance, Congress Proceedings, pp. 68-69).

\section{References}

1. Abd Ellah M.R.: Oxidant and antioxidants during the transition period in dairy cows. J Adv Vet Res 2016, 6, 130-133.

2. Aitken S.L., Karcher E.L., Rezamand P., Gandy J.C., VandeHaar M.J., Capuco A.V., Sordillo L.M.: Evaluation of antioxidant and proinflammatory gene expression in bovine mammary tissue during the periparturient period. J Dairy Sci 2009, 92, 589-598.

3. Alila-Johansson A., Eriksson L., Soveri T., Laakso M.L.: Serum cortisol levels in goats exhibit seasonal but not daily rhythmicity. Chronobiol Int 2003, 20, 65-79.

4. Appasamy M., Jauniaux E., Serhal, P., Al-Qahtani A., Groome N.P., Muttukrishna S.: Evaluation of the relationship between follicular fluid oxidative stress, ovarian hormones, and response to gonadotropin stimulation. Fertil Steril 2008, 89, 912-921.

5. Bernabucci U., Ronchi B., Lacetera N., Nardone A.: Influence of body condition score on relationships between metabolic status and oxidative stress in periparturient dairy cows. J Dairy Sci 2005, 88, 2017-2026.

6. Bernabucci U., Ronchi B., Lacetera N., Nardone A.: Markers of oxidative status in plasma and erythrocytes of transition dairy cows during hot season. J Dairy Sci 2002, 85, 2173-2139.

7. Bhat S., Rao G., Murthy D.K., Bhat P.G.: Seasonal variations in markers of stress and oxidative stress in rats. Indian J Clin Biochem 2008, 23, 191-194.

8. Castillo C., Hernandez J., Bravo A., Lopez-Alonso M., Benedito J.L.: Oxidative status during late pregnancy and early lactation in dairy cows. Vet J 2005, 169, 286-292. 
9. Castillo C., Hernandez J., Valverde I., Pereira V., Sotillo J., Alonso M.L., Benedito J.L.: Plasma malonaldehyde (MDA) and total antioxidant status (TAS) during lactation in dairy cows. Res Vet Sci 2006, 80, 133-139.

10. Cigliano L., Strazzullo M., Rossetti C., Grazioli G., Auriemma G., Sarubbi F., Iannuzzi C., Iannuzzi L., Spagnuolo M.S.: Characterization of blood redox status of early and mid-late lactating dairy cows. Czech J Anim Sci 2014, 59, 170-181.

11. Daley C.A., Macfarlane M.S., Sakurai H., Adams T.E.: Effect of stress-like concentrations of cortisol on follicular development and the preovulatory surge of LH in sheep. J Reprod Fertil 1999, 117, 11-16.

12. Das R., Sailo L., Verma N., Bharti P., Saikia J., Imtiwati, Kumar R.: Impact of heat stress on health and performance of dairy animals: A review.Vet World 2016, 9, 260-268.

13. Dash S., Chakravarty A.K., Singh A., Upadhyay A., Singh M., Yousuf S.: Effect of heat stress on reproductive performances of dairy cattle and buffaloes: A review. Vet World 2016, 9, 235-244.

14. De Rensis F., Lopez-Gatius F., García-Ispierto I., Morini G., Scaramuzzi R.J.: Causes of declining fertility in dairy cows during the warm season. Theriogenology 2017, 15, 145-153.

15. De Rensis F., Scaramuzzi R.J.: Heat stress and seasonal effects on reproduction in the dairy cow - a review. Theriogenology 2003, 60, 1139-1151.

16. Festila I., Miresan V., Raducu C., Cocan D., Constantinescu R., Coroian A.: Evaluation of oxidative stress in dairy cow through antioxidant enzymes glutathione peroxidase (GPX) and superoxide dismutase (SOD). Bulletin UASVM Anim Sci Biotechnol 2012, 69, 107-110.

17. Fox P.F., Kelly A.L.: Indigenous enzymes in milk, overview and historical aspects - part 2. Int Dairy J 2006, 16, 517-532.

18. Gong J., Xiao M.: Selenium and antioxidant status in dairy cows at different stages of lactation. Biol Trace Elem Res. 2016, 171, 89-93.

19. Hafeman D.G., Sunde R.A., Hoekstra W.G.: Effect of dietary selenium on erythrocyte and liver glutathione peroxidase in the rat. J Nutr 1974, 104, 580-587.

20. Halliwell B., Gutteridge J.M.C.: Free radicals in biology and medicine. Oxford University Press. Grune Strottan, New York, 2007.

21. Komesaroff P.A., Esler M., Clarke I.J., Fullerton M.J., Funder J.W.: Effects of estrogen and estrous cycle on glucocorticoid and catecholamine responses to stress in sheep. Am J Physiol 1998, 275, 671-678.

22. Konvicna J., Vargova M., Pulikova I., Kovac G., Kostecka Z.: Oxidative stress and antioxidant status in dairy cows during prepartal and postpartal periods. Acta Vet Brno 2015, 84, 133140.

23. Kumar J., Madan A.M., Kumar M., Sirohi R., Yadav B., Reddy A.V., Swain D.K.: Impact of season on antioxidants, nuritional metabolic status, cortisol and heat shock proteins in Hariana and Sahiwal cattle. Biol Rhythm Res 2017, doi:10.1080/09291016.2017.1332842.

24. Kurokawa Y., Yamashita R., Okita M., Yoshitoshi R., Sugino T., Obitsu T., Kawamura K.: A comparision of plasma glucose and oxidative status in lactating dairy cows in summer and autumn. Anim Sci J 2016, 87, 1212-1217.

25. Leblanc S.J.: Monitoring metabolic health of dairy cattle in the transition period. J Reprod Dev 2010, 56, 29-35.

26. Lutosławska G., Tkaczyk J., Panczenko-Kresowska B., HubnerWozniak E., Skierska E., Gajewski A.K.: Plasma TBARS, blood GSH concentrations, and erythrocyte antioxidant enzyme activities in regularly menstruating women with ovulatory and anovulatory menstrual cycles. Clin Chim Acta 2003, 331, $159-163$.

27. Maibam U., Hooda O.M., Sharma P.S., Singh S.V., Upadhyay R.C.: Seasonal change in oxidative stress markers in blood plasma of Tharparkar (Bos indicus) and Karan Fries (Bos indicus $\mathrm{x}$ Bos taurus) cattle under tropical climate. Int J Curr Microbiol App Sci 2017, 6, 1720-1730.

28. Megahed G.A., Anwar M.M., Wasfy S.I., Hammadeh M.E.: Influence of heat stress on the cortisol and oxidant-antioxidants balance during oestrous phase in buffalo-cows (Bubalus bubalis): Thermo-protective role of antioxidant treatment. Reprod Dom Anim 2008, 43, 672-677.

29. Mudron P., Konvicna J.: Thiobarbituric acid reactive substances and plasma antioxidative capacity in dairy cows at different lactation stages. Dtsch Tierarztl Wochenschr 2006, 113, 189-191.

30. Omidi A., Fathi M.H., Parker M.O.: Alterations of antioxidant status in dairy cows during lactation and in the dry period. J Dairy Res 2017, 84, 49-53.

31. Orzechowski A., Ostaszewski P., Brodnicka A., Wilczak J., Jank M., Balasinska B., Grzelkowska K., Ploszaj T., Olczak J., Mrowczynska A.: Excess of glucocorticoids impairs wholebody antioxidant status in young rats. Relation to the effect of dexamethasone in soleus muscle and spleen. Horm Metab Res. 2000, 32, 174-181.

32. Ozkaya M.O., Nazıroglu M.: Multivitamin and mineral supplementation modulates oxidative stress and antioxidant vitamin levels in serum and follicular fluid of women undergoing in vitro fertilization. Fertil Steril 2010, 94, 2465-2460.

33. Pilarczyk B., Jankowiak D., Tomza-Marciniak A., Pilarczyk R., Sablik P., Drozd R., Tylkowska A., Skolmowska M.: Selenium concentration and glutathione peroxidase (GSH-Px) activity in serum of cows at different stages of lactation. Biol Trace Elem Res 2012, 147, 91-96.

34. Rizzo A., Mutinati M., Spedicato M., Minoia G., Trisolini C., Jirillo F., Sciorsci R.L.: First demonstration of an increased serum level of reactive oxygen species during the peripartal period in the ewes. Immunopharmacol Immunotoxicol 2008, 30, 741-746.

35. Sakatani M., Balboula A.Z., Yamanaka K., Takahashi M.: Effect of summer heat enviroment on body temperature, estrous cycles, and blood antioxidant levels in Japanese Black cow. Anim Sci J 2012, 83, 394-402.

36. Saleh M., Salam A., Mileegy I.H.M.: Oxidative antioxidant status during transition from late pregnancy to early lactation in native and cross bred cows in the Egyptian oasis. Assiut Vet Med J 2007, 53, 113.

37. Sharma N., Singh N.K., Singh O.P., Pandey V., Verma P.K.: Oxidative stress and antioxidant status during transition period in dairy cows. Asian-Aust. J Anim Sci 2011, 24, 479-484.

38. Simonov M., Petruh I., Vlizlo V.: Processes of lipid peroxidation and antioxidant defense in dairy cows depending on lactation period and season. Rocz Nauk Zoot 2015, 42, 107-115.

39. Sordillo L.M., Aitken S.L.: Impact of oxidative stress on the health and immune function of dairy cattle. Vet Immunol Immunopathol 2009, 128, 104-109.

40. Sundrum A.: Metabolic disorders in the transition period indicate that the dairy cows' ability to adapt is overstressed. Animals 2015, 5, 978-1020.

41. Sunil Kumar B.V., Kumar A., Meena K.: Effect of heat stress in tropical livestock and different strategies for its amelioration. J Stress Physiol Biochem 2011, 7, 45-54.

42. Turk R., Podpecan O., Mrkun J., Flegar-Mestric Z., Perkov S., Zrimsek P.: The effect of seasonal thermal stress on lipid mobilisation, antioxidant status and reproductive performance in dairy cows. Reprod Dom Anim 2015, 50, 595-603.

43. Uchiyama M., Mihara M.: Determiantion of malonaldehyde precursor in tissues by thiobarbituric acid test. Anal Biochem 1978, 86, 271-278

44. Wolfenson D., Sonego H., Bloch A., Shaham-Albalancy A., Kaim M., Folman Y., Meidan R.: Seasonal differences in progesterone production by luteinized bovine thecal and granulosa cells. Domest Anim Endocrinol 2002, 22, 81-90. 